\title{
Detection of Exposure to Microplastics in Humans: A Systematic Review
}

\author{
Sarinah Basri $\mathrm{K}^{1,2 * \mathbb{D}}$, Anwar Daud ${ }^{2}$, Ratna Dwi Puji Astuti ${ }^{2}$, Basri $\mathrm{K}^{3}$ \\ ${ }^{1}$ Department of Public Health, Faculty of Public Health, Universitas Wiralodra, Indramayu, Indonesia; ${ }^{2}$ Department of \\ Environmental Health, Faculty of Public Health, Universitas Hasanuddin, Makassar, Indonesia; ${ }^{3}$ Department of Technology \\ and Vocational Education, FKIP Universitas Nusa Cendana, Kupang, Indonesia
}

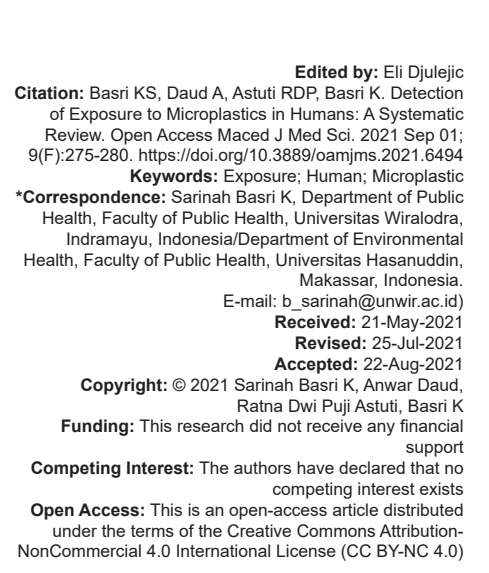

Abstract

BACKGROUND: Microplastics are able to enter the human body through food chains, personal care products contact (skin) from the soil, water or inhalation of microplastics in the air.

\begin{abstract}
AIM: This article aims to identify the presence of microplastics that are exposed to humans.
\end{abstract}
METHODS: Systematic review using four bibliographic databases (Google Scholar, Wiley Online Library, PubMed, and Science Direct). Literature search from 2016 to 2021, in the search found as many as 10983 papers extracted using PRISMA guidelines, a total of five papers were selected for review.

RESULTS: In this review article, the presence of oral, dermal, and inhalation exposed microplastics is found in feces, colon, placenta, scalp hair, hand skin, facial skin, and saliva. Several methods are used to identify microplastics according to polymer types, shape, and sizes microplastics in humans. The polymer type often found in the article is polypropylene. In addition, fibers, fragments and films are detectable shape of microplastic, while the size of microplastics $>5 \mathrm{~mm}$.

CONCLUSION: This literature study provides evidence that microplastics of various types of polymers, shapes and sizes are ubiquitous in humans. Hence, the possibility of health risks resulting from microplastic exposure in the human body should not be ignored.

\section{Introduction}

Production and use of plastics have continued to increase over the past 30 years [1]. It is estimated that plastics production will increase by $40 \%$ by 2030 [2]. The world produces more than 400 million tons of plastics every year, most of which are considered mismanaged after use [3]. Inadequate disposal of plastics becomes a threat to aqueducts, soil and possibly air [4]. Large amounts of plastics waste are released into the environment over many years eventually decomposing into microplastics [5], gradually degraded by weathering and aging [1]. Microplastics are environmental pollutant [6]. Its widespread abundance and distribution in the world are what many scientists use as key indicators of the recent and contemporary periods that define a new historical age [7].

The most exposed to the most microplastics organisms may be human because they are at the peak of the food chain [8]. Humans are potentially exposed to microplastics through food, beverages, and air [9], as well as skin contact because of the microplastics in the products [10] that is, through the use of personal care products (scrub soap, toothpaste, and facial washing), cosmetics [11] and contact (skin) from the soil [12]. In cars and toys, microplastics can also be found [11]. Microplastics are usually smaller than non-synthetics particles and thus identified can be inhaled [9]. Because of their small size, they can be inhaled and can cause lesions on the respiratory system depending on individual vulnerability and the nature of the particles [13].

An important contributor to the human who may exposte is drinking water [14]. In addition to oral feeding that involves contaminated water consumption also through food products (plants and seafood) [12] and contact with food packaging [15]. Oral exposure has been an important route of microplastics exposure for organisms [16]. Microplastics swallowed through food enter the human body. They interact with the phlegic structure of the digestive tract first and are subsequently relocated to the lymphatic and circulatory systems and through which they reach and accumulate in the organ, resulting in human health [17]. If inhaled or ingested, microplastics can accumulate and use local particle toxicity by encouraging or enhancing the immune response [6]. Therefore, in the study of this literature, we aim to review some papers that detect the presence of microplastics in the human body. 


\section{Materials and Methods}

\section{Search strategy}

Searching of the literature review for identifying relevant papers with question studies uses four bibliography databases: Google scholar, Wiley Online Library, PubMed, and Science Direct. All four databases are used as search engines to find the article that qualifies the review. The search strategy uses keywords of Detection OR Presence OR Abundance AND Exposure AND Microplastics AND Human. Based on keywords search, it was first discovered in 10983 articles, Google scholar (8560) Wiley Online Library (309), Science direct (1935) dan PubMed (179). This search is done from 2016 to 2021.

\section{Study selection}

Systematic reviews would be helpful to synthesize a variety of relevant research results. The search for research was done systematically followed the correct research stages or protocols by using methods of Preferred Reporting Items for Systematic Reviews and Meta-analyses or commonly called PRISMA.

\section{Data extraction}

Literature accessed in the research process by having screenings based on the inclusion and exclusion criteria is suggested in Table 1. In the systematic review of data literacy, we first looked at the publication year and read the title and abstract so that it could be known on the topic. Then, we read the entire text by reviewing the methods used in microplastic identification, results and conclusions. At this stage, it is defined the criteria of the data found, whether they are worthy of being used as data sources. Here is the seemingly worthy criterion.

Table 1: The exclusion and inclusion criteria in the literature search

\begin{tabular}{ll}
\hline Criteria & Description \\
\hline Eksklusi & Editorials, letters, book, encyclopedia, \\
& Non-English articles \\
& Double publication \\
Inclusion & There is no limit on age, gender and research location \\
& Detecting microplastics exposure to human specimens \\
& Microplastics detected in the human body \\
& Examining size, shape and type of microplastics polymer \\
& Full text \\
\hline
\end{tabular}

Of the 10983 articles extracted from four databases (Figure 1), after screening had been made, this data extraction results could be known for further analysis. Based on screening and due diligence, a number of eligible articles found are five articles published only in 2019-2021 since the search for the year 2016-2018 articles does not fit the criteria.

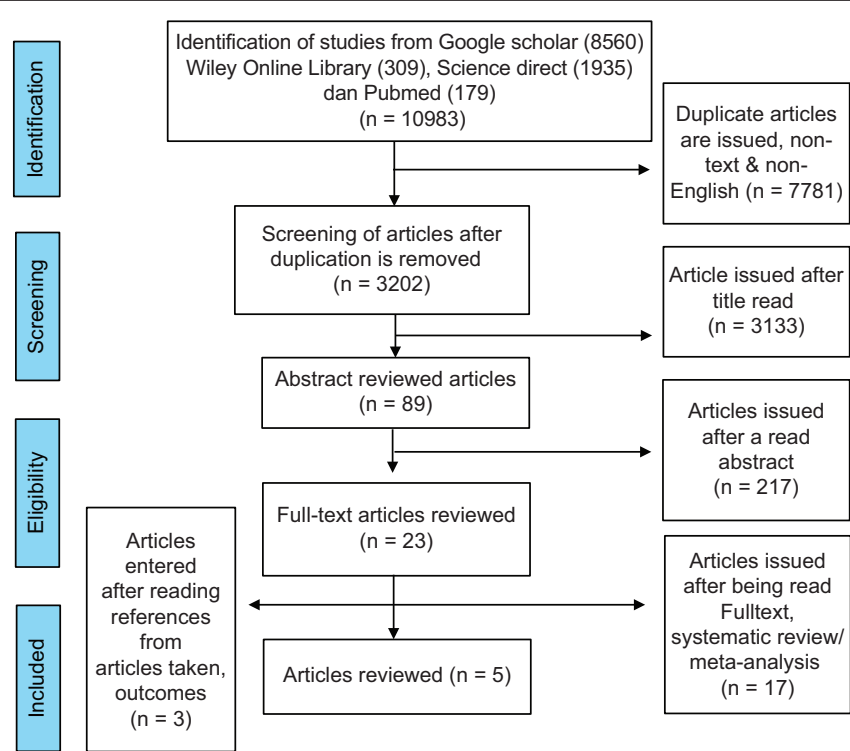

Figure 1: PRISMA Flow Diagram

\section{Data analysis}

The data collected at the previous stage will be analyzed at this stage. The results analyzed will address any research question that has been predetermined. Syndicated items in the selected articles based on topics are arranged into five main parts; (1) specimen (2) polymer type (3) shape, (4) size of microplastics, and (5) exposure route.

\section{Results and Discussion}

\section{Microplastics in human specimen}

Previous studies have done a lot of microplastics studies in both air, soil, water, animals, and plants. Based on the literature study, microplastics are also found in the human body as seen in Table 2 . In microplastics analysis, it can be used microscope Fourier transform infrared (FT-IR) [18], [19], [20] to identify the types and numbers of particles [20] and Raman microspectroscopy to evaluate the presence of microplastics and its poly composition [21], [22]. To analyze the microplastics sample is more often using FT-IR spectroscopy, but Raman spectroscopy also has the same value in analyzing the sample in microplastics research [23].

The consumption of microplastics in the search for the literature review is not restricted to age and gender, but the literature shows that microplastics are greater in men than in women (ratio of approximately $2: 1$ ). In total, the number of microplastics observed is lower in the hair of the female head than in the hair of the male head [21] because the annual microplastics consumption of humans depends on age 
and gender [24]. Literature studies show that in the human body, microplastics are found in samples of the hair of the head, the skin of the hands, the face and the saliva. Most of the top microplastics samples are hair with an average value of $>3.5$ microplastics per person per day and saliva with an average value of 0.33 microplastics per person per day [21].

The sample of the colectomy by detecting an average of 331 particles per individual specimen or 28 particles per $\mathrm{g}$ of the colon was the first human study using a sample of the colectomy so that no similar data could be compared [19]. The first study of human samples found in the placenta is as many as 12 microplastics fragments with details of 5 microplastics found in the fetus' side, 4 in the mother's side and 3 in the chorioamniotic membranes [22]. Another is the presence of microplastics found in human feces, by detecting 20 microplastic particles at $10 \mathrm{~g} \mathrm{(s)}$ of feces [20]. In addition, the presence of microplastics in the literature study was found at 26 students at Beijing Sport University in China with the microplastics abundance varying from 1 particle/g up to 36 particles/g [18]. In humans, the average daily excretion of wet feces is $128 \mathrm{~g} /$ bonnet/day or the dry mass median of $29 \mathrm{~g} /$ bonnet/day [25].

This literature review suggests that an abundance of microplastics has been found in human feces, meaning its existence is beyond doubt. Another study which corroborates that microplastics evidence is also found in feces is microplastics research in animal feces such as microplastics found in $92 \%$ of sheep feces [26], 55\% of the most common microplastics and $41 \%$ of microplastics fibers found in seal feces [27] and $47 \%$ of feces precursor samples in seabirds [28].

\section{Polymer type, shape, and size of microplastics}

Various types of polymers, shapes, and sizes of microplastics detected in human feces are shown in Table 3. The literature study of human feces indicates that the polymers detected are polypropylene, polyethylene terephthalate and polystyrene, but as many as 23 of the 24 fecal samples of the highest proportion were polypropylene with a relative mass abundance ratio $(61 \%)$. Although the microplastics shape was not analyzed, the use of microplastics may contain fibers such as packaged water and toothache [18]. As to other fecal samples, of the nine types of plastics that are totally detected, the most abundance of polymer is polypropylene, and polyethylene terephthalate is rarely spherical or fiber, largely in the shape of film and fragments [20].

Microplastics fragments were also detected by Raman Microspectroscopy in human placenta samples obtained from six patients. The result shows that there are 12 fragments with a round or irregular shape, where three is polypropylene a thermoplastic polymer and nine is only pigments [22]. Microplastics are detected in 11 colectomies containing $90 \%$ of polycarbonate, $50 \%$ of polyamide, and $40 \%$ of polypropylene with the most common particle shape is $96.1 \%$ of filament or fiber. The colored microplastics ingested by humans may then be "bleaching" during the colic transit by the digestive enzymes in the human body so that the filament found is $73.1 \%$ of transparent filaments [19]. The polymer type identified in the study in Iran consists of polyethylenepolyethylene terephthalate and polypropylene fibers measuring $<100 \mu \mathrm{m}$. Fibers range from small and relatively thick strands to thinner, longer and curved strings [21]. Polypropylene is the most common polymer detected in literature studies, whereas fragments and fibers are what appear to be detected in its shape. Along with the needs of the world's plastics, the most reported shape is fragments and fibers [29]. When viewed from size, microplastics have the smallest measurements in the sample of the plasenta 5 to $10 \mu \mathrm{m}$ [22] and $<100 \mu \mathrm{m}$ [21] while the largest in the sample collection sample 0.8 to $1.6 \mathrm{~mm}$ [19], the sample size $<5 \mathrm{~mm}$ [18] is not specifically stated in the research. Microplastics are defined as having particles of $1 \mathrm{~nm}-5 \mathrm{~mm}$ [30].

Table 3: The presence of microplastics by polymer type, shape, and size

\begin{tabular}{|c|c|c|c|}
\hline Polymer type & Shape & Size & References \\
\hline $\begin{array}{l}\text { Polycarbonate, polyamide and } \\
\text { polypropylene }\end{array}$ & Filament or fiber & $0.8-1.6 \mathrm{~mm}$ & [19] \\
\hline $\begin{array}{l}\text { Polypropylene and polyethylene } \\
\text { terephthalate }\end{array}$ & Fragment and films & $50-500 \mu \mathrm{m}$ & [20] \\
\hline Polypropylene & Fragment & $5-10 \mu \mathrm{m}$ & [22] \\
\hline $\begin{array}{l}\text { Polyethylene or polyethylene } \\
\text { terephthalate, polypropylene, polystyrene } \\
\text { polyvinyl chloride }\end{array}$ & fiber & $<100 \mu \mathrm{m}$ & [21] \\
\hline Polypropylene & Not analyzed & $<5 \mathrm{~mm}$ & [18] \\
\hline
\end{tabular}

Polypropylene

\section{Microplastics exposure route in human}

body

A literature review of the microplastics exposure route in the human body is shown in Table 4 and Figure 2. Exposure routes of microplastics can be through inhalation, dermal, or oral [31].

Table 2: Microplastics biomarker

\begin{tabular}{|c|c|c|c|c|c|c|}
\hline \multirow[t]{2}{*}{ Name (Year) } & \multirow[t]{2}{*}{ Location } & \multirow[t]{2}{*}{ Study Participant } & \multicolumn{2}{|c|}{ Total } & \multirow[t]{2}{*}{ Biomarker specimen } & \multirow[t]{2}{*}{ Identification } \\
\hline & & & $\overline{\mathrm{W}}$ & $\mathrm{M}$ & & \\
\hline Yusof Shuaib Ibrahim, et al. (2020) & $\begin{array}{l}\text { Northeastern } \\
\text { Peninsular, Malaysia }\end{array}$ & $\begin{array}{l}9 \text { subjects are suffered from a colorectal } \\
\text { cancer while } 2 \text { have a normal colon }\end{array}$ & 5 & 6 & Colectomy & FT-IR \\
\hline Philipp Schwabl, MD et al. (2019) & Europe and Asia & Healthy volunteers & 5 & 3 & Feces & FT-IR \\
\hline Antonio Ragusa et al. (2021) & Rome (Italy) & Woman with normal labor & 6 & - & Placenta & Raman microspectroscopy \\
\hline Sajjad Abbasia \& Andrew Turnerb (2021) & Iran & Heathy male students & 3 & 3 & Head, hand, and face hair and saliva & Raman microspectroscopy \\
\hline $\mathrm{Na}$ Zhang et al. (2021) & Beijing, China & Young adults & - & 26 & Feces & FT-IR \\
\hline
\end{tabular}


Table 4: Microplastics exposure route

\begin{tabular}{lll}
\hline Exposure route & Source & Reference \\
\hline Oral, Inhalation & Seafoods, operating chamber, laboratory & {$[19]$} \\
Oral, Dermal & Seafoods consumption, plastics bottle drink, and used & {$[20]$} \\
& cosmetics product use & \\
Dermal & Cosmetics use & {$[22]$} \\
Oral, Dermal & Toothpaste, furniture and clothes & {$[21]$} \\
Oral & Liquid and food intake & {$[18]$} \\
\hline
\end{tabular}

Exposure can occur with swallow, inhale and skin contact due to microplastics in products, foodstuffs and air [10]. Plastic particles found in a sample of colone are derived from seafood consumption [19]. During diet surveys of 3 days, as many as $5(20.8 \%)$ participants ate seafood at least once [18] while other reviews state that none of the participants are vegetarian because as many as six participants were found consuming seafood during the observation period. The food was stored and wrapped in a plastic container. It was also found that seven participants drank from plastic bottles every day [20]. While seafood consumption such as shellfish may be the main exposure route, but significant causal factors through inhaled microplastics should also be considered [19]. Microplastics in air can also be exposed to hair because fibers are very easily transferred when dressed or undressed or when exposed to appliances in synthetic textiles [21]. Rooms that can also be contaminated with microplastics such as operating and laboratory environments cannot be ignored [19]. The use of various cosmetics such as lipstick, mascara, eye shadow, and other products can also affect microplastics exposure. Possible entryway and transport of microplastics is from the respiratory organs and the stomach to the placenta [22]. Synthetic polymer is also contained in 3 used cosmetic products (such as face wash, shower gel, and hand cream) [20].

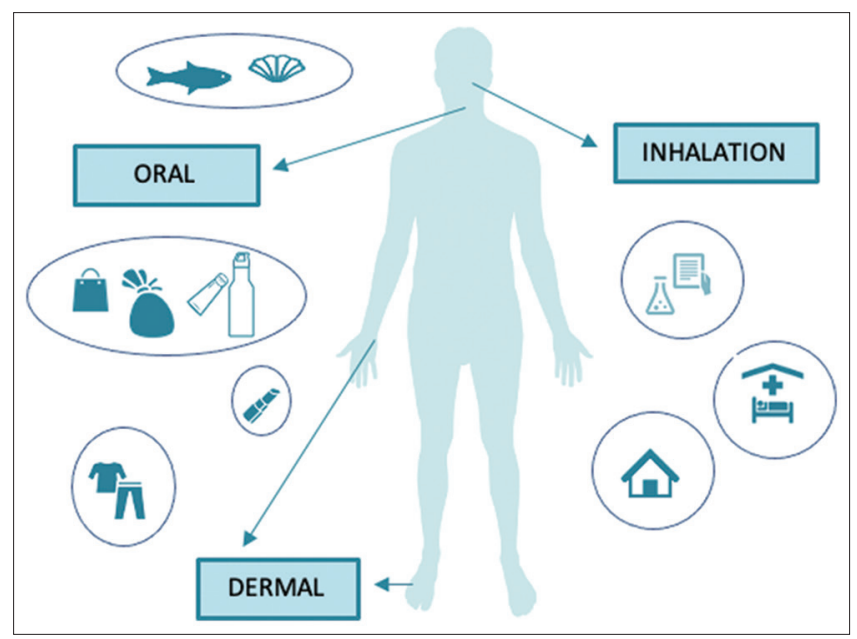

Figure 2: Exposure route and source of microplastics

Microplastics human exposure to food chains, contact with food packaging and air consumption that causes some health effects [6], [15], [32], [33] also impacts on dermal associated with exposure to monomers and plastic additives [10]. In the literature study, individuals with increased permeability of intestine who suffer from disease inflammation may have a higher risk of translocation of microplastic particles [19]. The presence of microplastics in the placenta is potentially harmful to pregnancies and in the fetus potentially effects plasticizer regeneration on reproduction and metabolism [22]. While acute and chronic health effects are unknown, chronic inflammation of the lungs will occur at considerable levels which lead to the formation of reactive oxygen species and secondary effects [21]. Therefore, it should be noted for the limits of microplastics consumption in humans. From various exposure routes, every human life can only consume microplastics of 0.1 to $5 \mathrm{~g}$ [34] or ranging from 39,000 and 52,000 microplastic particles per year [24]. In studies, it has limited numbers of samples, so further analysis is needed by setting up a larger sample of specimen. Furthermore, in a microplastics human body can cause a release of toxic contaminants from harmful plastics, so further study of the addictive substance in the microplastics in the human body of those living specimen has a chronic and acute effect.

\section{Conclusion}

Humans have the potential for microplastics exposure through food, drink, food packaging, personal care products, cosmetics as well as air. Using microscope FT-IR and Raman microspectroscopy, it can be identified the presence of microplastics both polymer type, shape, and size of microplastics found in the human body as well as in feces, colon, placenta, head hair, hand skin, facial skin and saliva. Based on the previous studies the health risk of microplastics exposure cannot be ignored. Humans who consume microplastics via various exposure routes can be minimized by considering the recommended microplastics intake in both ages and genders. For further study, it requires a larger number of samples and their effect on humans.

\section{References}

1. Paul MB, Stock V, Cara-Carmona J, Lisicki E, Shopova S, Fessard V, et al. Micro and nanoplastics-current state of knowledge with the focus on oral uptake and toxicity. Nanoscale Adv. 2020;2(10):4350-67. https://doi.org/10.1039/d0na00539h

2. Advisors $D$, de Wit W, Bigaud N. Assessing Plastic Ingestion from Nature to People. An Analysis for WWF; 2019. p. 7.

3. World Economic Forum. Plastics, the Circular Economy and Global Trade. World Economic Forum; 2020. p. 22.

4. Amato-Lourenço LF, dos Santos Galvão L, de Weger LA, Hiemstra PS, Vijver MG, Mauad T. An emerging class of air pollutants: Potential effects of microplastics to respiratory human health? Sci Total Environ. 2020;749:141676. https://doi. 
org/10.1016/j.scitotenv.2020.141676

PMid:32827829

5. Liu J, Zhang T, Piché-Choquette S, Wang G, Li J. Microplastic pollution in China, an invisible threat exacerbated by food delivery services. Bull Environ Contam Toxicol. 2020;2020:03018-1. https://doi.org/10.1007/s00128-020-03018-1

PMid:33078289

6. Wright SL, Kelly FJ. Plastic and human health: A micro issue? Environ Sci Technol. 2017;51(12):6634-47.

PMid:28531345

7. Campanale C, Massarelli C, Savino I, Locaputo V, Uricchio VF. A detailed review study on potential effects of microplastics and additives of concern on human health. Int $\mathrm{J}$ Environ Res Public Health. 2020;17(4):1212. https://doi.org/10.3390/ ijerph17041212

PMid:32069998

8. Enyoh CE, Shafea L, Verla AW, Verla EN, Qingyue W, Chowdhury T, Paredes M. Microplastics exposure routes and toxicity studies to ecosystems: An overview. Environ Anal Health Toxicol. 2020;35(1):1-10.

9. Vianello A, Jensen RL, Liu L, Vollertsen J. Simulating human exposure to indoor airborne microplastics using a Breathing Thermal Manikin. Sci Rep. 2019;9(1):1-11. https://doi. org/10.1038/s41598-019-45054-w

10. Prata JC, Costa JP, Lopes I, Duarte AC. Centre for environmental and marine studies (CESAM) and department of chemistry. Sci Total Environ. 2019;2019:134455.

11. Kontrick AV. Microplastics and human health: Our great future to think about now. J Med Toxicol. 2018;14(2):117-9. https://doi. org/10.1007/s13181-018-0661-9

PMid:29687221

12. Enyoh CE, Shafea L, Verla AW, Verla EN, Qingyue W, Chowdhury $\mathrm{T}$, et al. Microplastics exposure routes and toxicity studies to ecosystems: An overview. Environ Health Toxicol. 2020;35(1):e2020004. https://doi.org/10.5620/eaht.e2020004 PMid:32570999

13. Prata JC. Airborne microplastics: Consequences to human health? Environ Pollut. 2018;234:115-26.

PMid:29172041

14. Danopoulos E, Twiddy M, Rotchell JM. Microplastic contamination of drinking water: A systematic review. PLoS One. 2020;15(7):e0236838. https://doi.org/10.1371/journal. pone.0236838

PMid: 32735575

15. Hwang J, Choi D, Han S, Choi J, Hong J. An assessment of the toxicity of polypropylene microplastics in human derived cells. Sci Total Environ. 2019;684:657-69. https://doi.org/10.1016/j. scitotenv.2019.05.071

PMid:31158627

16. Wu B, Wu X, Liu S, Wang Z, Chen L. Size-dependent effects of polystyrene microplastics on cytotoxicity and efflux pumpinhibition in human Caco-2 cells. Chemosphere. 2019;221:333-41. https://doi.org/10.1016/j.chemosphere.2019.01.056 PMid:30641374

17. Rao BM. Review Microplastics in the aquatic environment: Implications for post-harvest fish quality. Indian $J$ Fish. 2019;66(1):142-52. https://doi.org/10.21077/ ijf.2019.66.1.83125-20

18. Zhang N, Li YB, He HR, Zhang JF, Ma GS. You are what you eat: Microplastics in the feces of young men living in Beijing. Sci Total Environ. 2021;767:144345.

19. Ibrahim YS, Anuar ST, Azmi AA, Khalik WM, Lehata S, Hamzah SR, et al. Detection of microplastics in human colectomy specimens. JGH Open. 2021;5(1):116-21. https://doi. org/10.1002/jgh3.12457

20. Schwabl P, Köppel S, Königshofer P, Bucsics T, Trauner M, Reiberger $\mathrm{T}$, et al. Detection of various microplastics in human stool: A prospective case series. Ann Intern Med. 2019;171(7):453-7. https://doi.org/10.7326/m19-0618 PMid:31476765

21. Abbasi S, Turner A. Human exposure to microplastics: A study in Iran. J Hazard Mater. 2020;403:123799.

PMid:33264903

22. Ragusa A, Svelato A, Santacroce C, Catalano P, Notarstefano V, Carnevali $\mathrm{O}$, et al. Plasticenta: First evidence of microplastics in human placenta. Environ Int. 2021;146:106274. https://doi. org/10.1016/j.envint.2020.106274

PMid:33395930

23. Stark M. Letter to the editor regarding "are we speaking the same language? Recommendations for a definition and categorization framework for plastic debris. Environ Sci Technol. 2019;53(9):4677. https://doi.org/10.1021/acs.est.9b01360 PMid:31021604

24. Cox KD, Covernton GA, Davies HL, Dower JF, Juanes F, Dudas SE. Human consumption of microplastics. Environ Sci Technol. 2019;53(12):7068-74. https://doi.org/10.1021/acs.est.9b01517 PMid:31184127

25. Rose C, Parker A, Jefferson B, Cartmell E. The characterization of feces and urine: A review of the literature to inform advanced treatment technology. Crit Rev Environ Sci Technol. 2015;45(17):1827-79. https://doi.org/10.1080/10643389.2014.1 000761

PMid:26246784

26. Beriot N, Peek J, Zornoza R, Geissen V, Lwanga EH. Low density-microplastics detected in sheep faeces and soil: A case study from the intensive vegetable farming in Southeast Spain. Sci Total Environ. 2021;755:142653. https://doi.org/10.5194/ egusphere-egu21-7376

27. Donohue MJ, Masura J, Gelatt T, Ream R, Baker JD, Faulhaber $\mathrm{K}$, et al. Evaluating exposure of northern fur seals, Callorhinus ursinus, to microplastic pollution through fecal analysis. Mar Pollut Bull. 2018;138:213-21. https://doi. org/10.1016/j.marpolbul.2018.11.036

PMid:30660265

28. Provencher JF, Vermaire JC, Avery-Gomm S, Braune BM, Mallory ML. Garbage in guano? Microplastic debris found in faecal precursors of seabirds known to ingest plastics. Sci Total Environ. 2018;644:1477-84. https://doi.org/10.1016/j. scitotenv.2018.07.101

PMid:30743860

29. Zhang $Y$, Kang $S$, Allen S, Allen D, Gao T, Sillanpää $M$. Atmospheric microplastics: A review on current status and perspectives. Earth Sci Rev. 2019;203:103118. https://doi. org/10.1016/j.earscirev.2020.103118

30. European Commission's Group of Chief Scientific Advisors. Environmental and Health Risks of Microplastic Pollution, No. 6. European Commission's Group of Chief Scientific Advisors; 2019.

31. Chang X, Xue Y, Li J, Zou L, Tang M. Potential health impact of environmental micro and nanoplastics pollution. J Appl Toxicol. 2020;40(1):4-15. https://doi.org/10.1002/jat.3915 PMid:31828819

32. Yi W, Tang DY, Khoo KS, Lup AN, Chew KW. Environmental Science and ecotechnology nature's fight against plastic pollution: Algae for plastic biodegradation and bioplastics production. Environ Sci Ecotechnol. 2020;4:100065. https://doi. org/10.1016/j.ese.2020.100065

33. Bradney L, Wijesekara $\mathrm{H}$, Palansooriya KN, Obadamudalige $\mathrm{N}$, Bolan NS, Ok YS, et al. Particulate plastics as a vector for toxic trace-element uptake by aquatic and terrestrial organisms and 
human health risk. Environ Int. 2019;131:104937. https://doi. org/10.1016/j.envint.2019.104937

PMid:31284110

34. Senathirajah K, Attwood S, Bhagwat G, Carbery M, Wilson S,
Palanisami T. Estimation of the mass of microplastics ingested a pivotal first step towards human health risk assessment. J Hazard Mater. 2021;404(Pt $\quad$ B):124004. https://doi. org/10.1016/j.jhazmat.2020.124004

PMid:33130380 